\title{
Instalasi Audio Sebagai Penunjang Proses Pendidikan Pada Pondok Pesantren Al Mubasysyirun Kecamatan Pemenang Kabupaten Lombok Utara
}

\author{
Suthami Ariessaputra*, Cahyo Mustiko Okta Muvianto, Warindi, \\ Syafaruddin Ch, Budi Darmawan
}

Jurusan Teknik Elektro, Universitas Mataram, Mataram, Indonesia

\begin{abstract}
Kata Kunci: $\quad$ Abstrak: Desa Pemenang Timur Kecamatan Pemenang Kabupaten Lombok Utara Pondok

Pesantren Al merupakan salah satu wilayah yang terkena dampak gempa Lombok tahun 2018.

Mubasysyirun, Gempa tersebut menyebabkan jatuhnya korban jiwa dan kerusakan sarana fisik. Audio, Instalasi, Pelatihan dan level audio Banyak fasilitas umum yang rusak termasuk juga tempat ibadah dan fasilitas pendidikan. Pondok pesantren Al Mubasyssyirun yang terletak di Desa Pemenang Timur juga mengalami kerusakan bangunan sekolah dan sarana penunjang pendidikan seperti komputer dan peralatan audio berupa pengeras suara. Fasilitas audio digunakan sebagai sarana penunjang proses kegiatan belajar mengajar antara lain untuk memberikan informasi kepada warga sekolah berupa pengumuman dan suara dari bel sekolah sebagai pemberi tanda bahwa kegiatan belajar mengajar akan dimulai atau berakhir. Selain itu, peralatan pengeras suara dapat digunakan dalam kegiatan upacara bendera. Kualitas audio yang dihasilkan dipengaruhi oleh peralatan audio yang digunakan dan cara instalansi peralatan tersebut. Pemilihan peralatan pengeras suara harus memperhatikan lokasi penempatan, daya listrik yang tersedia dan jangkuan suara yang dihasilkan. Selain itu juga harus memperhatikan tingkat kebisingan yang dihasilkan. Oleh karena itu, melalui kegiatan Pengabdian Pada Masyarakat Kemitraan (PPM-K) dilakukan kegiatan instalasi, pelatihan penggunaan dan perawatan peralatan audio kepada guru, staff dan siswa pondok pesantren Al Mubasysyirun. Penempatan dan instalasi peralatan audio dengan memperhatikan kondisi lingkungan, letak bangunan dan spesifikasi masing-masing peralatan audio tesebut. Selain itu pihak pondok pesantren juga dapat mengetahui jenis-jenis peralatan audio dan cara perawatannya.
\end{abstract}

Korespondensi: suthami@unram.ac.id

\section{PENDAHULUAN}

Pondok pesantren dan Sekolah menjadi bagian yang penting dalam proses peningkatan kualitas sumber daya manusia. Pondok Pesantren Al Mubasysyirun merupakan salah satu penyelenggara pendidikan keagamaan yang berdiri pada tahun 1997. Pondok Pesantren Al Mubasysyirun beralamat di Jl. TGH. Hasan Basri Desa Pemenang Timur, Pemenang, Kabupaten Lombok Utara, Propinsi Nusa Tenggara Barat. Pondok pesantren Al Mubasysyirun menyelenggarakan pendidikan Madrasah Aliyyah dan Madrasah Tsanawiyyah. Jumlah santri di Pesantren Al Mubasysyirun adalah 151 orang, dengan rincian jumlah santri pria sejumlah 69 orang dan santri perempuan berjumlah 82 orang, dengan tenaga pengajar dan pegawai berjumlah 14 orang. 

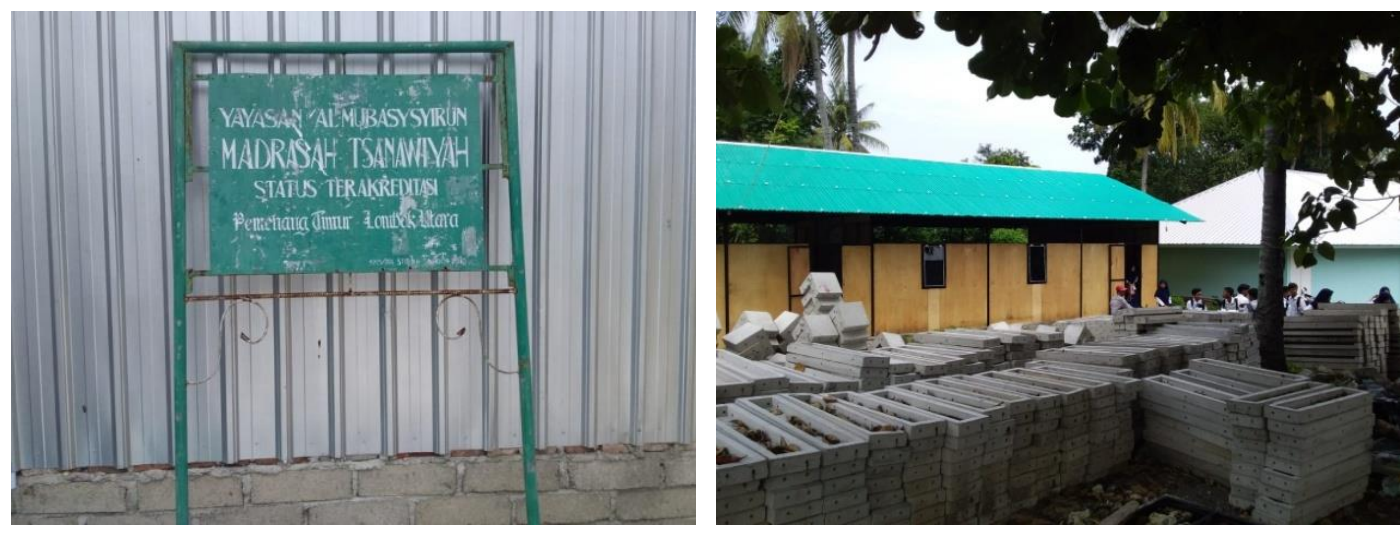

Gambar 1.Kondisi Pondok pesantren al Mubasysyirun pasca gempa

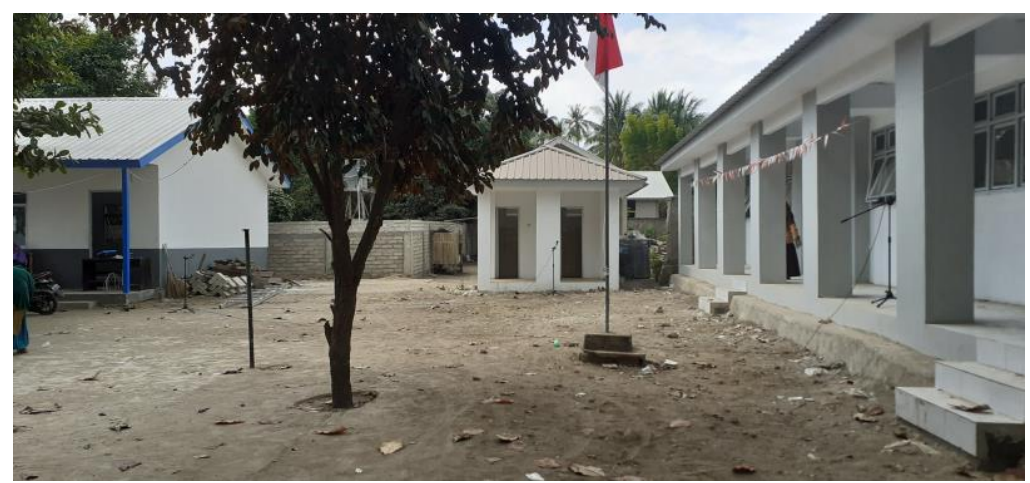

Gambar 2. Bangunan permanen Pondok Pesantren Al Mubasysyirun

Bencana gempa yang mengguncang pulau Lombok pada tanggal 5 agustus 2018 menyebabkan banyaknya korban jiwa dan juga mengakibatkan kerusakan pada bangunan serta sarana fisik lainnya (Pradono, 2018). Gempa ini juga mengakibatkan sarana dan prasarana Pondok Pesantren Al Mubasysyirun menjadi rusak sehingga sudah tidak bisa digunakan kembali. Bangunan utama seperti asrama, masjid, dan ruang kelas mengalami rusak berat. Pasca gempa, pada akhir tahun 2018 Pondok Pesantren Al Mubasysyirun mendapat bantuan bangunan semi permanen yang dapat dilihat pada gambar 1. Selanjutnya pada tahun 2019 pondok pesantren mendapatkan bantuan bangunan sekolah dari pemerintah seperti tampak pada gambar 2.

Selain bangunan yang rusak berat, peralatan audio yang selama ini mendukung kegiatan pendidikan di Pondok Pesantren Al Mubasysyirun juga ikut rusak. Perangkat audio yang dimiliki oleh Pondok Pesantren Al Mubasysyirun ikut tertimpa reruntuhan bangunan gedung sekolah sehingga menjadi rusak dan tidak dapat digunakan kembali.

Peralatan audio dapat digunakan sebagai sarana pendukung kegiatan perkantoran, peribadatan, hiburan dan kegiatan masyarakat (Ariessaputra et al, 2018). Selain itu peralatan audio juga dapat menunjang kegiatan belajar mengajar di Sekolah (Wati, 2016). Peralatan audio dapat digunakan sebagai bel sekolah yang berfungsi untuk menginformasikan pergantian jam pelajaran, tanda istirahat, tanda masuk kelas dan pulang sekolah. Pengembangan teknologi bel sekolah terbagi menjadi dua bidang yaitu perangkat keras dan perangkat lunak. Pengembangan perangkat lunak terbagi dua, yaitu aplikasi bel untuk desktop dan aplikasi mobile yang berbasis android (Linarta et al, 2018). 
Peralatan audio dapat digunakan untuk memberikan informasi berupa pengumuman pengumuman melalui pengeras suara sehingga dapat didengar oleh warga sekolah dan juga dapat melatih kemampuan menyimak siswa (Kesumawidayani et al, 2013). Selain itu peralatan audio dapat mendukung kegiatan upacara bendera sehingga pelaksanaan upacara bendera menjadi lebih khidmat. Perlu ada pengaturan dan penempatan posisi peralatan audio yang tepat sehingga diperoleh hasil yang maksimal. Kegiatan upacara bendera dapat menumbuhkan semangat dan jiwa nasionalisme kepada para siswa (Prastiwi, 2016).

Permasalahan yang terjadi di pondok pesantren $\mathrm{Al}$ mubasysyirun adalah tidak tersedianya perlatan audio yang dapat digunakan untuk menunjang sarana kegiatan belajar mengajar di sekolah pasca gempa. Sehingga perlu penggantian dan pemasangan peralatan audio yang baru. Solusi yang ditawarkan adalah pemasangan peralatan audio yang memiliki multifungsi. Pertama, Peralatan ini dapat digunakan untuk memberikan informasi berupa pengumuman melalui pengeras suara. Kedua, juga dapat berfungsi sebagai bel sekolah yang dapat digunakan untuk memberikan informasi bahwa tanda masuk kelas, pergantian jam pelajaran dan info pulang sekolah. Ketiga, peralatan audio tersebut juga dapat digunakan pada kegiatan upacara bendera.

\section{METODE KEGIATAN}

Kegiatan pengabdian ini menggunakan metode penelitian lapangan berupa identifikasi masalah, studi literatur, analisis kebutuhan, Perancangan, instalasi peralatan, pengukuran kualitas, pelatihan penggunaan dan perawatan. Selanjutnya dilakukan evaluasi terhadap kegiatan yang telah dilakukan.

\section{Identifikasi Masalah}

Kegiatan identifikasi masalah meliputi survei lokasi, diskusi dan wawancara serta memeriksa sarana dan prasarana penunjang Sekolah yang masih dapat digunakan. Survei dilakukan pada Pondok Pesantren Al Mubasysyirun, yang beralamat di Jl. Tgh. Hasan Basri Desa Pemenang Timur, Pemenang, Kabupaten Lombok Utara, Propinsi Nusa Tenggara Barat pada hari sabtu tanggal 20 Juli 2019. Adapun tim yang ikut survei adalah : Suthami, Cahyo Mustiko, Budi darmawan, Warindi dan Syafaruddin.

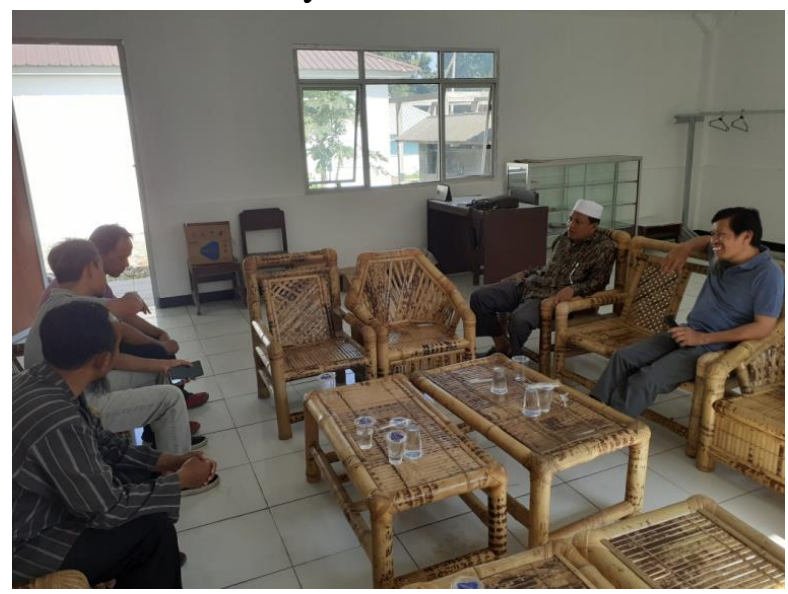

Gambar 3. Diskusi dengan pihak sekolah 
Kegiatan diskusi dan wawancara dilakukan antara tim pengabdian Universitas Mataram dengan kepala sekolah seperti tampak pada gambar 3. Berbagai informasi dan permasalahan serta solusi dibahas pada kegiatan ini. Pemeriksaan sarana prasarana meliputi layout bangunan sekolah, sumber listrik dan sarana pendukung yang dimiliki oleh sekolah seperti terlihat pada gambar 4. Pengukuran level kebisingan juga dilakukan di sekitar sekolah.

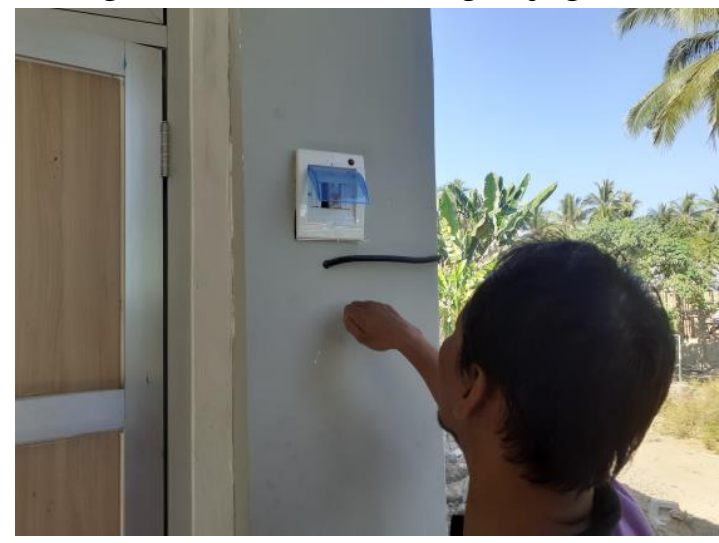

Gambar 4. Pengukuran Listrik

Sumber listrik sekolah berasal dari PLN dengan daya 1300 VA. Terdapat beberapa ruang kelas, ruang kepala sekolah ruang guru dan beberapa ruangan seperti terlihat pada gambar 5 .

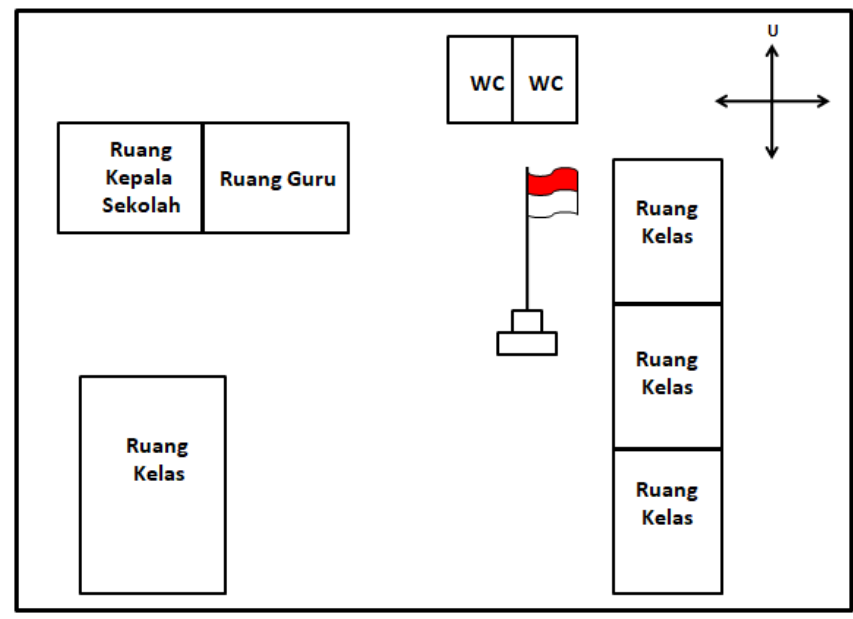

Gambar 5. Denah sekolah

\section{Analisis Kebutuhan}

Kebutuhan kegiatan pengabdian ini meliputi perangkat keras dan perangkat lunak.

1. Perangkat Keras

Perangkat keras yang dibutuhkan meliputi peralatan input, pemrosesan dan output. Spesifikasi perangkat keras dapat dilihat pada tabel 1 . 
Tabel 1. Spesifikasi kebutuhan perangkat keras

\begin{tabular}{|c|c|c|c|}
\hline No. & Alat & Spesifikasi & Jumlah \\
\hline 1 & Amplifier & $\begin{array}{l}\text { Output : } 30 \text { Watt } \\
\text { Konsumsi Daya : } 34 \text { Watt } \\
\text { Input mic : } 3 \text { Mic } \\
\text { Speaker output : Floating balanced } 100 \mathrm{~V}, 330 \text { ohm, 4-16 } \\
\text { ohm, } 15 \mathrm{~V} \\
\text { Respon Frekuensi : } 50-20.000 \mathrm{~Hz}\end{array}$ & 1 buah \\
\hline 2 & Microphone & $\begin{array}{l}\text { Mic ergonomic } \\
\text { Moving coil mikropon } \\
\text { Phone Plug }\end{array}$ & 1 buah \\
\hline 3 & Kabel Listrik & kabel listrik serabut $2 \mathrm{X} 0,75$ & 20 meter \\
\hline 4 & Stand mic & $\begin{array}{l}\text { Tripod kaki } 3 \\
\text { Mic Holder : } 2 \text { yaitu slide dan clip model holder) }\end{array}$ & 1 buah \\
\hline 5 & Microphone & $\begin{array}{l}\text { Include } 1 \text { holder mic } \\
\text { Panjang kabel : } 7.5 \text { meter } \\
\text { Konektor : Jek phone (akai) standar mono }\end{array}$ & 2 buah \\
\hline 6 & $\begin{array}{l}\text { Speaker Corong } \\
\text { (horn) }\end{array}$ & $\begin{array}{l}\text { Rated Input } 25 \text { Watt }(100 \mathrm{~V} \text { line }) \\
\text { High Impedance } \\
\text { Frequency Response: } 150 \sim 6.000 \mathrm{~Hz} \\
\text { Sound Preasure Level: } 110 \mathrm{~dB}(1 \mathrm{~W} / 1 \mathrm{~m} \text {, in anechoic } \\
\text { chamber) }\end{array}$ & 1 buah \\
\hline 7 & Kabel RCA & $\begin{array}{l}\text { Panjang } 1.5 \mathrm{~m} \\
\text { Gold plated connector }\end{array}$ & 1 buah \\
\hline
\end{tabular}

2. Perangkat Lunak

Perangkat lunak yang dibutuhkan adalah aplikasi bel sekolah berbasis android. Aplikasi ini berfungsi untuk mengatur waktu bel berbunyi dan untuk menandakan pelajaran dimulai atau telah berakhir.

\section{Perancangan dan Instalasi peralatan}

Berdasarkan analisis kebutuhan maka perancangan peralatan audio harus memiliki multifungsi yaitu sebagai media penyampaian informasi di sekolah, sebagai bel sekolah dan dapat mendukung pelaksanaan kegiatan upacara bendera. Perancangan peralatan dapat dilihat pada gambar 6. Pada saat penyampaian pengumuman dan kegiatan upacara bendera maka input suara menggunakan microphone dan melalui input kabel RCA. Sedangkan pada saat menjadi bel sekolah perlu ada penambahan smartphone yang telah terpasang aplikasi bel yang berbasis android. Aplikasi ini juga berfungsi untuk mengatur input suara bel sekolah sesuai dengan yang diinginkan.

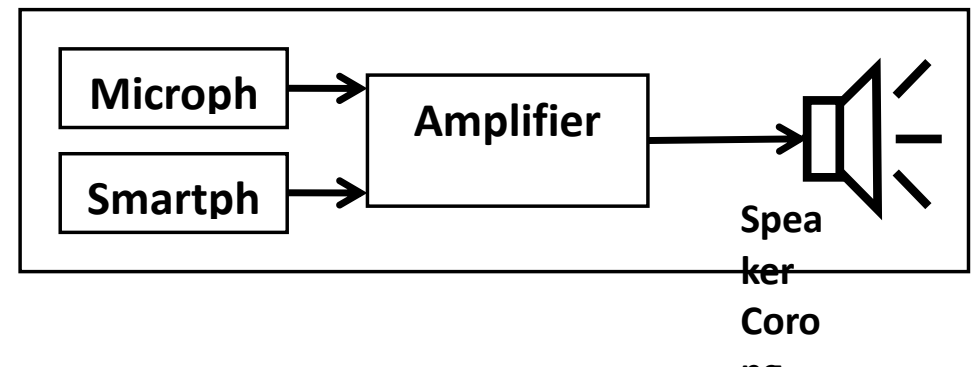

Gambar 6. Perancangan instalasi audio 
Tata letak penempatan peralatan audio dapat dilihat pada gambar 7. Amplifier di tempatkan diruang guru agar lebih aman dan mudah diakses oleh pihak sekolah. Speaker corong ditempatkan di bagian barat dan terletak ditengah agar dapat menjangkau area sekolah.

Pengaturan dan penempatan posisi peralatan audio pada saat upacara dapat dilihat pada gambar 8. Penempatan tersebut menyesuaikan dengan kondisi lingkungan sekolah dan untuk mendapatkan hasil yang maksimal.

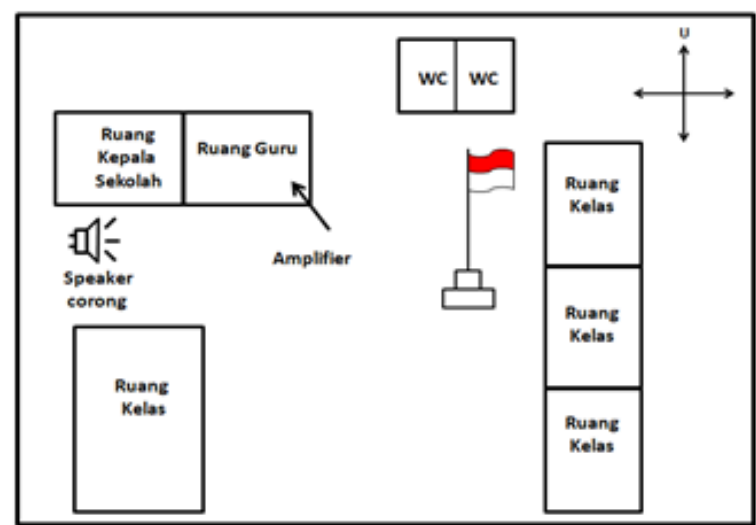

Gambar 7. Layout penempatan peralatan audio

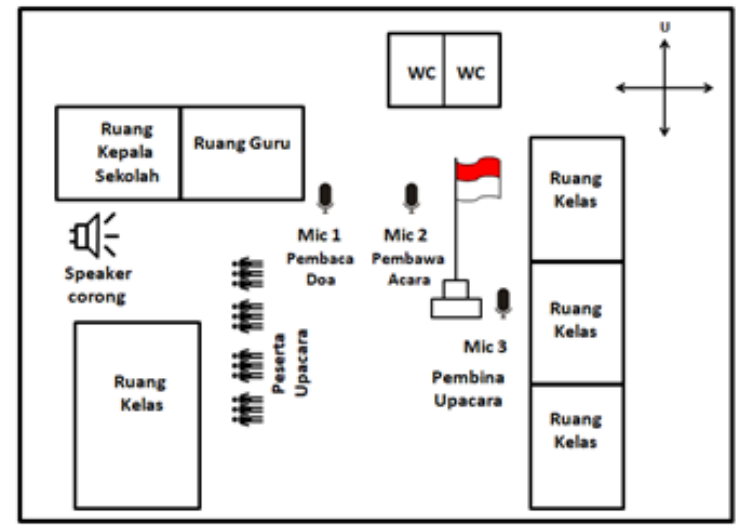

Gambar 8. Layout upacara bendera peralatan audio

\section{Pengukuran kualitas audio}

Pengukuran kualitas audio dilakukan menggunakan alat ukur sound level meter. Pengukuran level tekanan bunyi dBA dilakukan dalam rentan waktu selama 10 menit untuk tiap pengukuran dan pembacaan nilai level dilakukan setiap 5 detik. Standar nilai baku level kebisingan mengacu pada area perumahan dan permukiman yaitu sebesar 55dBA (KMLH, 1996).

\section{Pelatihan penggunaan dan perawatan}

Pelatihan Penggunaan dan Perawatan Peralatan Audio juga diberikan kepada guru, pegawai dan siswa. Kegiatan terdiri dari persentasi di kelas, praktek, diskusi dan Tanya jawab

\section{HASIL DAN PEMBAHASAN}

Tahapan dan uaraian hasil kegiatan yang telah dilakukan di Pondok Pesantren Al Mubasysyirun Kecamatan Pemenang Kabupaten Lombok Utara terdiri dari hasil instalasi, hasil pengukuran tingkat kebisingan dan Pelatihan penggunaan serta perawatan.

\section{Hasil Instalasi peralatan}

Pelaksanaan kegiatan meliputi: Instalasi dan perbaikan audio dan Pelatihan penggunaan audio Musholla Instalasi audio. Peralatan amplifier, microphone di tempatkan di dalam ruang guru dan diatas meja seperti terlihat pada gambar 9. Sedangkan instalasi kabel dilakukan dengan rapi dan menyesuaikan dengan kondisi ruangan seperti pada gambar 10 . Speaker corong di letakkan di luar ruangan sehingga mudah menjangkau seluruh area sekolah. 


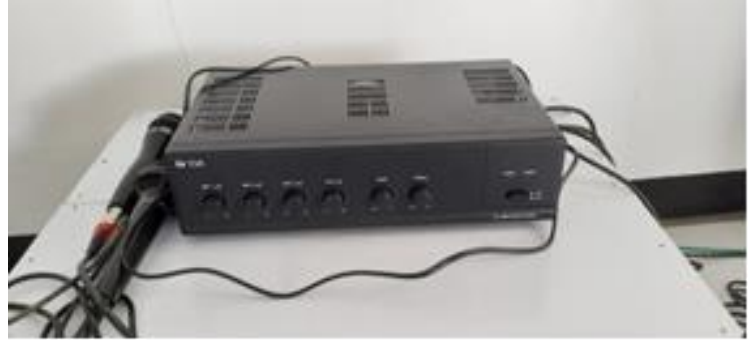

Gambar 9. Instalasi amplifier

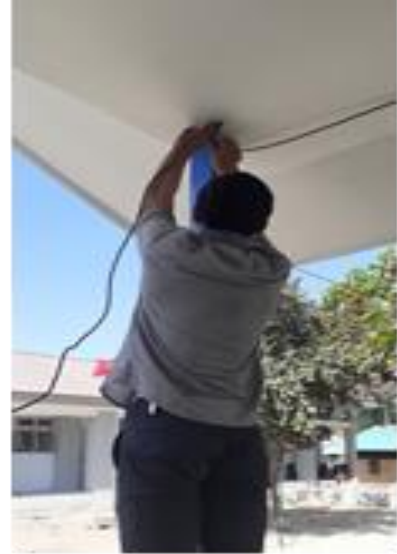

Gambar 10. Instalasi kabel

Posisi peralatan microphone dan stand mic menyesuaikan dengan posisi petugas upacara seperti terlihat pada gambar 11. Microphone dan stand mic berada pada tiga posisi yaitu: Pembaca do'a, pembawa acara dan pembina upacara. Pada saat peralatan audio berfungsi sebagia bel sekolah, maka inputan suara bel dilakukan melalui smartphone dengan menggunakan bantuan aplikasi android.

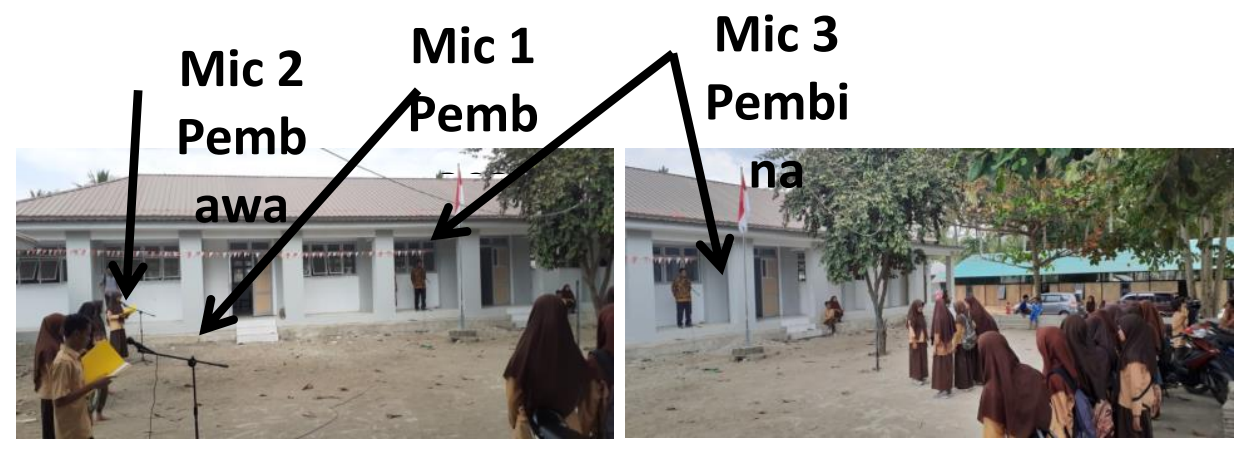

Gambar 11. Posisi saat upacara bendera

\section{Hasil Pengukuran Tingkat Kebisingan}

Pengukuran kualitas audio menggunakan alat sound level meter seperti terlihat pada gambar 12. Pengukuran dilakukan pada ruang kelas sebanyak 100 kali pengambilan sampel dengan nilai rata-rata level kebisingan sebesar $53.5 \mathrm{~dB}$.

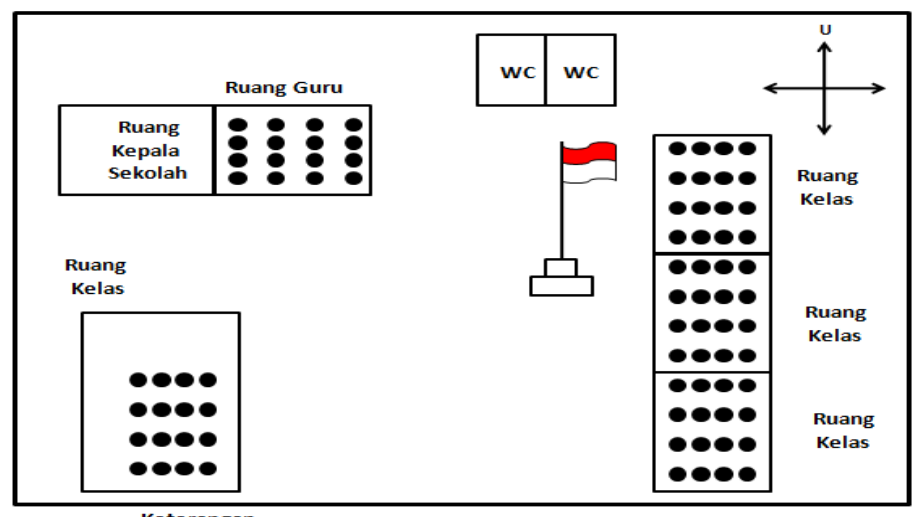

Keterangan $\underset{=}{=}$ posisi pengambilan sampel

Gambar 12. Posisi pengambilan sampel 


\section{Pelatihan penggunaan dan perawatan}

Pelatihan penggunaan dan perawatan terdiri dari ceramah, diskusi dan tanya jawab. Kegiatan ini terbagi menjadi tiga sesi. Sesi pertama pemataran materi oleh tim pengabdian. Sesi kedua adalah tanya jawab dan sesi ketiga pemberian hadiah bagi peserta yang dapat menjawab pertanyaan dengan benar. Materi pelatihan yang diberikan kepada guru, pegawai dan siswa tentang peralatan input dan output audio serta cara perawatannya seperti tampak pada gambar 13 .
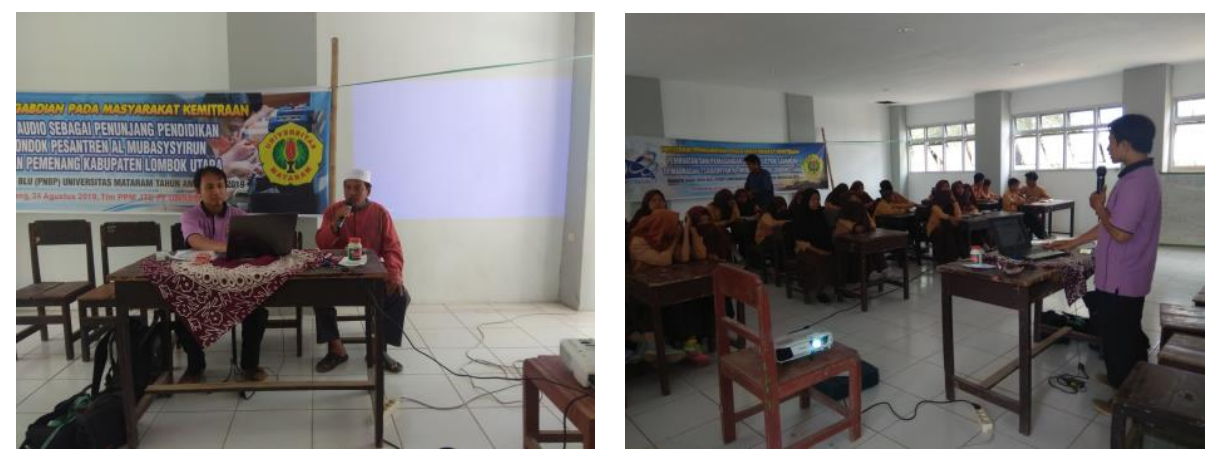

Gambar 13. Pemberian materi, diskusi dan tanya jawab.

Kegiatan pelatihan ini berjalan dengan baik, hal ini terlihat pada saat sesi tanya jawab banyak peserta yang ikut menjawab pertanyaan. Selanjutnya pada akhir acara diberikan hadiah kepada peserta yang dapat menjawab pertanyaan seperti terlihat pada gambar 14 .
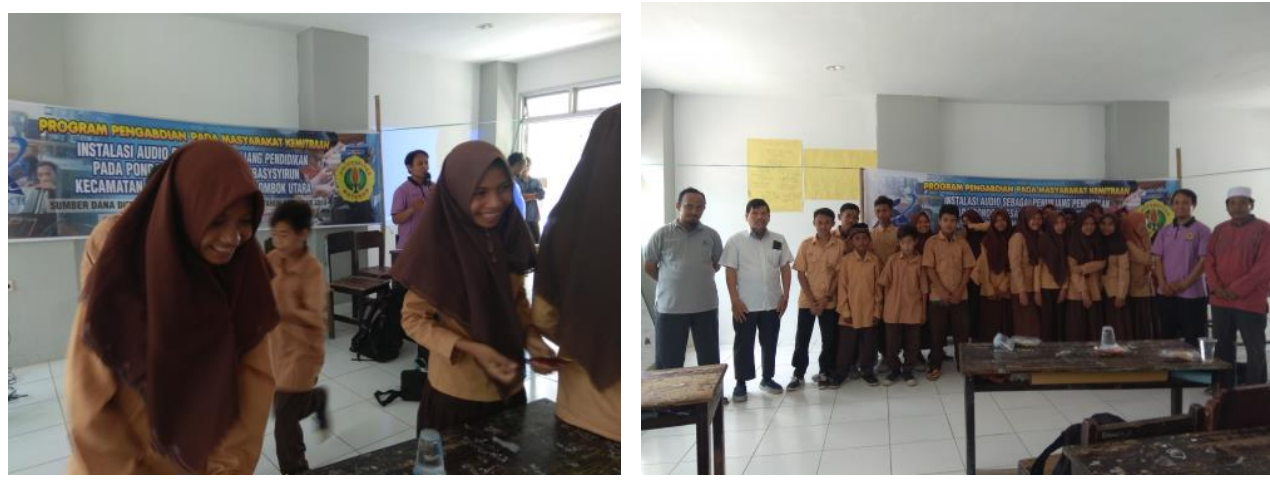

Gambar 14. Pemberian hadiah pada peserta

\section{KESIMPULAN DAN SARAN}

Kesimpulan dari kegiatan pengabdian instalasi audio di pondok pesantren Al Mubasysyirun adalah sebagai berikut :

1. Instalasi peralatan audio pada pondok pesantren Al Mubasysyirun memiliki multifungsi, yaitu: sebagai media pemberi informasi melalui pengeras suara, berfungsi sebagai bel sekolah serta dapat digunakan untuk mendukung kegiatan upacara bendera.

2. Pelatihan penggunaan dan perawatan peralatan audio dapat memberikan wawasan dan pengetahuan tambahan bagi guru, pegawai dan siswa pondok pesantren $\mathrm{Al}$ Mubasysyirun. 
Level audio yang dihasilkan memiliki tingkat kebisingan dibawah ambang batas yang diperbolehkan pada area lingkungan sekolah atau sejenisnya serta area pemukiman yaitu berada pada level dibawah $55 \mathrm{dBA}$.

\section{Ucapan Terima Kasih}

Terima kasih disampaikan kepada pihak Lembaga Penelitian dan Pengabdian Kepada Masyarakat (LPPM) Universitas Mataram yang telah membantu terlaksananya kegiatan Pengabdian Kepada Mayarakat di Pondok Pesantren Al Mubasysyirun Desa Pemenang Timur, Kecamatan Pemenang, Kabupaten Lombok Utara untuk instalasi audio dan kegiatan pelatihan penggunaan serta perawatannya.

\section{DAFTAR PUSTAKA}

Ariessaputra, S., Darmawan, B., Muvianto, C.M.O., Ch, S. 2018. Peningkatan Kualitas Audio di Musholla Al Huda Desa Gunungsari. Prosiding PKM-CSR Konferensi Nasional Pengabdian kepada Masyarakat dan Corporate Social Responsibilty. Mataram, 1 November.

Faradiba. 2017. Tingkat Kebisingan di Sekolah Sekitar Perlintasan Kereta Api. Prosiding SNFA (Seminar Nasional Fisika dan Aplikasinya). UKI:Jakarta.

Keputusan Menteri Lingkungan Hidup. 1996. Baku Kebisingan. Surat Keputusan Menteri Lingkungan Hidup Nomor: Kep-48/MENLH/1996/25 November 1996. Jakarta.

Kesumawidayani., Kresnadi, H., Marli, S. 2013. Penggunaan Media Audio Dalam Pembelajaran Bahasa Indonesia Untuk Meningkatkan Keterampilan Menyimak. Jurnal Pendidikan dan Pembelajaran Khatulistiwa, Vol 2, No 3 (Desember 2018).

Linarta, A., Nurhadi. 2018. Aplikasi Bel Sekolah Otomatis Berbasis Arduino dilengkapi Output Suara. Jurnal Informatika, Manajemen dan Komputer, Vol 10, No 2 (2013).

Pradono, M. H. 2018. Kajian Kerentanan Bangunan Pasca Gempa Lombok 5 Agustus 2018. Jurnal Alami: Jurnal Teknologi Reduksi Risiko Bencana, Vol 2, No 2 (2018):82-88.

Prastiwi, B.K. 2016. Meningkatkan Nilai Keindonesian Melalui Upacara Bendera Di Sekolah Dasar. Seminar Nasional KeIndonesiaan I. FPIPSKR. Universitas PGRI Semarang Wati, E.R. 2016. Ragam Media Pembelajaran. Kota Pena. 